摘 錄 分 類

1. 慜用力学及び栚栈力学

2. 工業材料及ざ材料学

3. 洞定機及已゙仴范法

4. 熱及び熟力学

5. 知料及び然点

6. 被氛発生率置

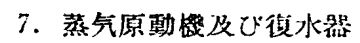
8. 内燃篗閶

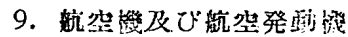

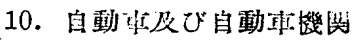

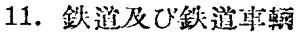
12. 船舶及び舶朋械哭

13. 流体力学及び水打

14. 压縮機及ひ选風嘰

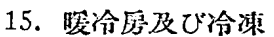

16. 機構及び機械設計

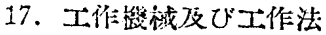

18. 跣造、銊造及び熔接

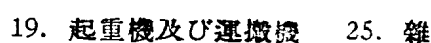

20. 紡緎

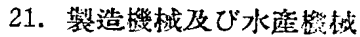

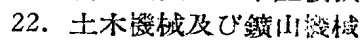

23. 工場管理及び経满

24. 工業敉者

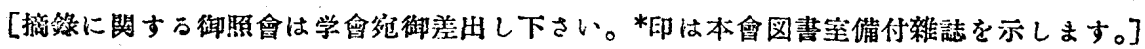

\title{
4. 熱.及び熱 カ 学
}

\section{[79] 各種熱交換器の 平均溫度差}

[R.A. Bowman; A.C. Mueller, W.M. Nagle, A.S.M.E. Trans.*, 1940-5, Vol. 62, No. 4, 頁 283〜294, 図 14, 表 2]

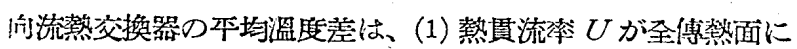
闪て定、(2) 両流体の流量と比熱が一定、(3) 傳熱面の一

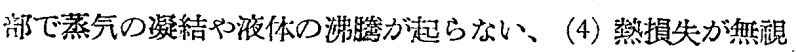
されるとの諸仮定条件下では、䋸知の対数平均溫度至 $\Delta t_{\mathrm{log}}$

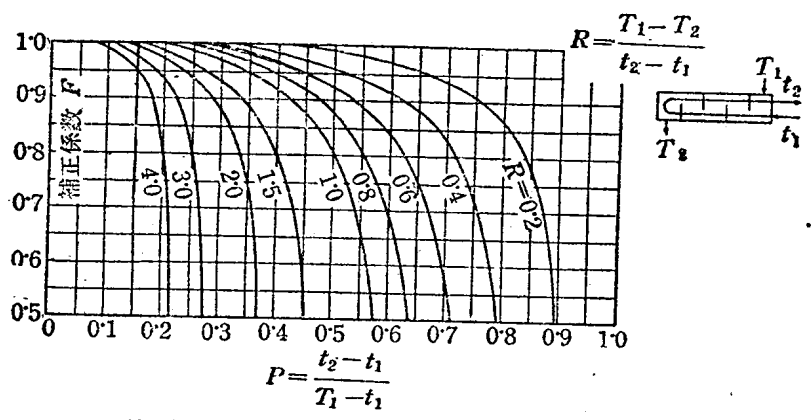

第 113 図 1-假数管路熱交換器の補正保数

となる。笑際に沶用される多管路や值交流熱交換器の平域温 戍差 $\Delta t_{m}$ はこれより低く、並流の平均溫度差との中間做で らる。

本墖文ではこれ等各種の熱交換器の $\Delta t_{m}$ に就て現在迄に 笔表された研究精果を一括し、 $\Delta t_{m}=F \cdot \Delta t_{\log }$ 之表はした場 合の補正係数 $F$ の線図が主要型式に就て與へてある。

多管路熱交換器(1) 上記の仮定条件 (1) （4) の他に、(5) 各管路の傳等面が等しい（6）管外流体溫度が流れに直何方 向に均等で方ると仮定方る。条件 (5) は普通の模浩のもので は常に满足される。条件 (6)は多数の横仕切(管に直南の数) を設けた侍に成立つ。叉、管外及び管付流体大口並に出口溫 透 $T_{1}, T_{2}, t_{1}, t_{2}$ を率元数 $P=\left(t_{2}-t_{1}\right),\left(T_{1}-t_{1}\right), R=\left(T_{1}-\right.$ $\left.T_{2}\right),\left(t_{2}-t_{1}\right)$ で至はす。

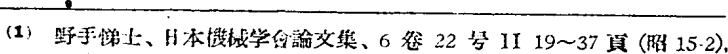

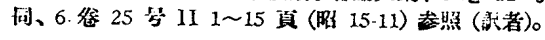

第 45 卷第 304 告]
}

管外路 ${ }^{(2)} 1$ - 管內路 ${ }^{(3)}$ 偶数の坳合 Nagle, Underwood, Bowman, Yendall の研究結果を綜合すれば、1-2 管路(4)の 場合の $F$ は第113 図の㥞に心り、1-4, 1-6 管路の F はこれ より渐娍宁るが事実上は第113図のものと一致斗る。更に管 內路数が重限に多くなれに゙、Bownan ガ指摘した椂にこれ は两流体か混合方直艾流となるが、この時のFも第113図 の倠より 1 2\% 低下立るに止まるから、結局 1一㛾数管路 のFは悉く第 113 図で與へられると帣へて差支へない。

管外路 2 以上の場合 等 113 図より $F$ を大きくしたい 時には絋仕切（管方向の板）を設けて 1 筒內を2管外路に

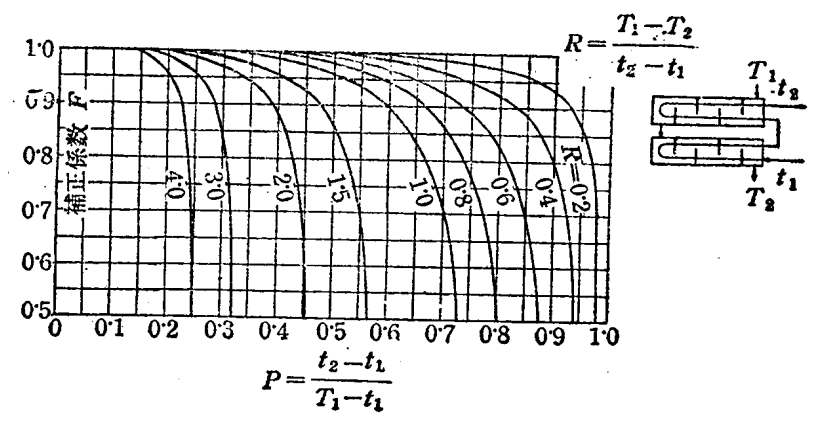

第 114 图 2-偶数管路热交換器つ補正保教

したり、更に2䈪上七を接続して琵置全体を问流に近付かせ る。この場合の維仕切を通る整流及び漏洩を門視して先づ Underwood は 2-4 管路の $F$ に対して第114図を求めた。 更にBowmanはこれを一般化して、1-2 管路を向流接続し て出来る $N-2 N$ 管路のものに対する $P_{N, 2 N}$ と、1-2 管路

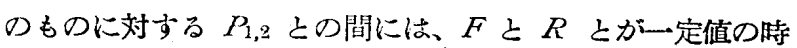
に次の関係が成立つことを明らかにした。

$$
P_{N, 2 N}=\frac{1-\left\{\left(1-P_{1,2} R\right) /\left(1-P_{1,2}\right)\right\}^{N}}{R-\left\{\left(1-P_{1,2} R\right) /\left(1-P_{1,2}\right)\right\}^{N}}
$$

但し $R=1$ ならば

$P_{N, 2 N}=P_{1,2} N /\left(P_{1,2} N-P_{1,2}+1\right)$

この関係を利用方れば 3-6，4-8，6-12 管路等に対方る $F$ の線図が作成され、管外路数つ㬐加と共に $F$ が 1 に潮近音
(4) 管外路 I, 管肉 
ることが示される。劣、これ等の諸結果は 1-2 管路の代り

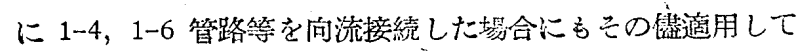
差支へない。

勿論管外路が並流接続の時の $F$ は土記よりも低いものに なる。

管內路数が奇数の場合 以上はことごとく管內路数が偶 数、従て向流管內路数が並流管內路数に等しい場合でらるか ら、管外流体の大口は筒の何れの侧におつても Fにば影響、 しない。

茲に Fischer は、管內路数を奇数にして、向流管闪路数 が並流管內路数よりも多くなる様に籄外流体入口を選定した 埸合に、同じ管外路数で管內路数が偶数の場合よりも $F$ が 幾分增進されることを指摘した。第 115 図は斯様な1-3 管路 の例を示市。

併しこれに因る $F$ の利得は管外路数增加に基つうくものよ りも少い。

熱買流率が一定でない場合 上記の仮定条件 (1) が成立 たない場合に対して、溫度 $T_{1}$ 側で $U=U_{1}, T_{2}$ 側で $U=$ $U_{2}$ とし、その中闑では $U$ が盜度に対して直線狀に変化市 ると仮定して向流に就て Colburn が求めた式から、Sieder, 'Tate は次の計筧式を提示してるる。

$$
\frac{\text { 傳筑量 }}{\text { 傳爇面皘 }}=(F) \frac{U_{2}\left(T_{1}-t_{2}\right)-U_{1}\left(T_{2}-t_{1}\right)}{2 \cdot 3 \log _{10}\left\{U_{2}\left(T_{1}-t_{2}\right) / U_{1}\left(T_{2}-t_{1}\right)\right\}}
$$

併しこの式は充分実証済になる迄は 1 管外路以外のものに は適用し難い。

設評に対する注意平场溫度差の点だけから云へば䇺外 路数を管內路数に等しくして純向流にするのが最る得策であ る。然るに棈造並に使用上の都合から管外路数には聂大限留

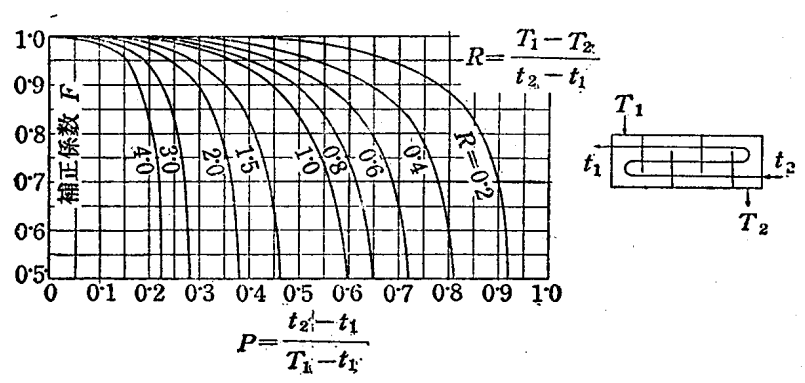

第 115 图 1-3 管路で 2 管內路が向流の 埸合の䘞证係数

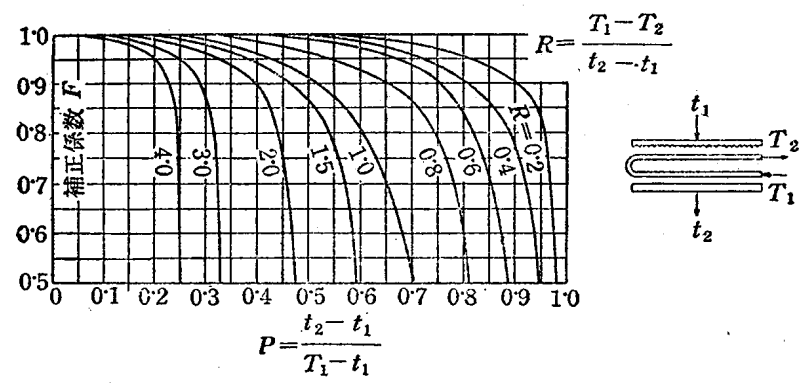

第 116 图 2 管路水平算琵㖇冷却器の補正你数、 往烈管の埸合
が号り、1“䇠當りの管外路数も2 以上に出出来ない。他方、 流量、䚺容圧力䅡失、占有空間、彆作費の点から管內路数に

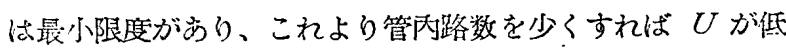
下して折角の $F$ の增淮が烸歌になる。故に設計順序として は先つ上記の榙慗情を洘虑して管内路数を定め、それから F が满足な大さに達する漛に管外路数を灌定し、2 管外路でも $F$ が不足の埸合には 2 筒以上を接続した方式を探用するに 至らのである。

第113〜115 図の示通り $F$ の値が小さい領域では $F$ 曲線

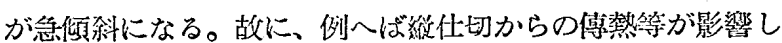
て、解に列挙した $F$ を算出方る際の仮定条件が正しく成立 たない場合には、平均溫度差に意外に大きな誤差を件なふ虞 がある。

洤て 0.8 以下の補正係数を設計に傎用することが果して 妥當であるかは疑はしい。Fが斯様に低くなつたときには寧 ろ管外路数を若干追加すべきである。同様な理由から F が 小さい条件下で得られた実驗結榡は一般的に通用させられ ない。

敍上の様に管外路當り3 管內路の蓺交換器では $F$ が幾分

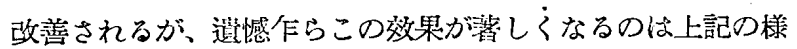
に䒠用に供し難いFの小さい領域に限られる。

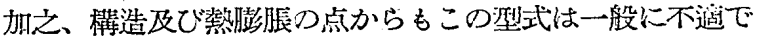
ある。

直交流熱交換器 權仕切を入れた多管路熱交換摆でも管 外流体は管に直交するが、この㭙には一仕切黨りの管外流体 溫度变化は微弱に過ぎ吉、結局》溫度勾配は管方向に生亦る から直交流とぱ看做されない。本来つ直交流つ平均溫应差に 就ては敘上の仮定策件 (1)〜(5) の他に、(6) 流体は流れに值 算に混合するかしないかの何えかとする、と仮定（実際つ策

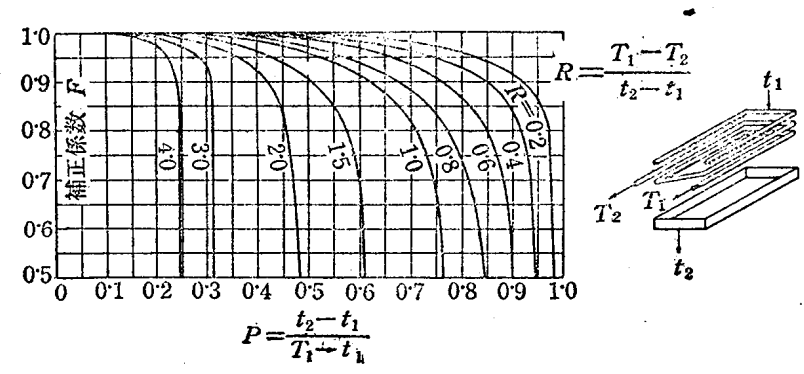

第 117 图 2 管路水平管裴垧冷却器の補正係数、 管コイルの場合

件下では湿合しないものに近いことが多い）して研究されて るる。併し斯样な研究は單管路の古型式と 2 管路の若干型式 に止まり、3 管路以上のものには未だ及ぼされてるない(5)。

單管路直交流管內流体を多数の細管に分歧させ、これ に直艾する管外流体の混合を多数の仕切板で阻比した埸合、 並に河面に細か心仕切を設けた板型直交流熱交換器は何れも 两流体が混合しない型式に該當し、この型式には Nusselt その他の研究がある。一方（例へば管內流体）は混合しない

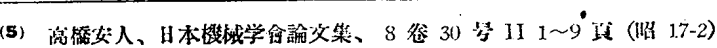
照 (初者)。 
が他つ流体が混合市る時、更に両流体共に混合市る埸合に就 ては Smith の仾究があり、Fは後者程低くなる。

2 管路直交流叙上の各種單管路直交流の組合せを考人 る上向流、並流接続に各 10 型式が数へられる。Smith が倩 いたのはその內の簡單な数䍿式だけである。管路間で一方の 流体が混合し、その他では車者共混合しない型式には Schumann の研究がある。この時の一管路は Nusselt の研究し た㨁交流と一致するが、他の管路では大口の溫度分布が均等

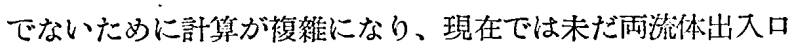
溫度から本均溫度差が與へられるには至つてるない。

その他の熱交換器 水平管を上下に配列し、その上から

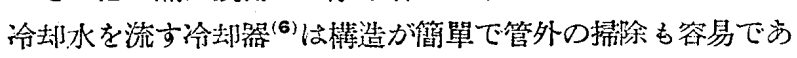
るために屡子用ひられる。その傳熱は一方（管闩）の流体が 混合し、他が湿合しない多管路直交流と看做され、往復管の ものは不混合流体が管路內で逆轉しない場合、管コイルのも のはこれが逆轉する場合に相當する。これ等の 2 管路のもの に第 116,117 図が與へておる。

次に、一方の流体が槽から槽へ溢流し、他の流体が各槽の 管コイルへ添られる方式がある。管內流体は管外（槽內）流 体に対して向流に接続することもあり、谷槽へ並列に供給す ることもある。各槽の管外流体温变を夫タ一定均等と仮定し て、全裝置出大口溫度から中間溫度を求める計算式及び図解 法が雨接続方式に対して提示してある。

最後に、一方の流体（溫度 $T$, 还期D初引に $T_{1}$, 終に $T_{2}$, 比䓡 $C$ ) の一定量 $M$ を傅熱面積 $A$ を通して他の流体（温 度 $t$, 大口温度 $t_{a}=$ 一定、出口温度 $t_{b}$, 比熱 $c$, 流最 $w$ ) で

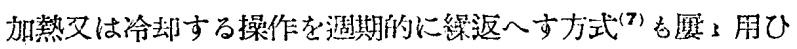

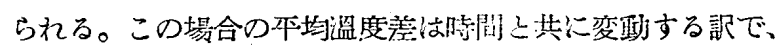
温度 $T$ が $M$ 全体に亘つて均等と俯定して Perry は次の式 を導いてるる。

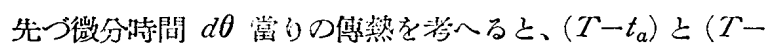
$\left.t_{b}\right)$ の対数平均を $(T-t)_{m}$ として、

$$
d T(T-t)_{m}=-U A d \theta_{i}(M C)
$$

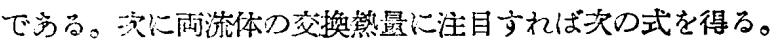

$$
w c\left(t_{b}-t_{a}\right) d \theta=-M C d T
$$

これ等両者から直ちに、

$$
\log _{e}\left\{\left(T-t_{a}\right) /\left(T-t_{b}\right)\right\}=A U /(w c)
$$

或はこれを 1 剧期 $\theta$ に静分して、 $\left(T_{1}-t_{a}\right)$ と $\left(T_{2}-t_{a}\right)$ の

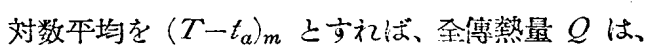

$$
Q=\tilde{w c} \theta\left(T-t_{a}\right)_{m}\left(1-e^{-\frac{A U}{w c}}\right)
$$

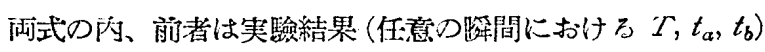
からUを檢討するのに好適である。又、後者に活 $t_{b}$ 方念

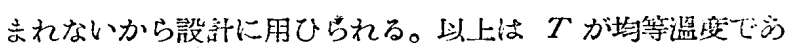
るとした場合であるが、この流体が全然混合しない時に淙不 定常熱傳導の問題になる。混合が不完奈な場合の平均温腰の 決定法ば未だ明らかにされてるない。

討議 Schumann 両流体が混合しない直交流熱交換器 のFが 1 より小さいことぱ、 $U$ が一定值ならば闰じ傳熱

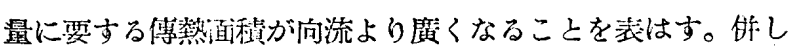
管外流体流量が多い㭙に好通のこの直艾流では、压打損失の

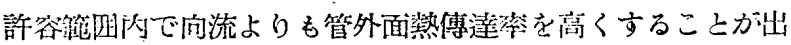

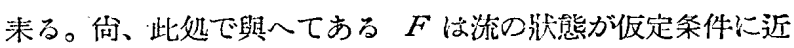
い酒交流に限つて信賴し得る候である。

落者 本諭文は各種熱艾捘器の平均温度差が $F$ を用ひ て簢毠に求的られる様に企図しだものである。勿諭 $F$ は向 流との真の比較を表はすもので活ない。向流以外の型式で $U$ の增進が $F$ の低下の影響を圧倒することも可能ではあるが、 型式に依ては $U$ の如何に拘ら实実現出未ない溫度条件のあ

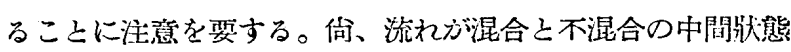
を呈する直交流の平均溫㹂奎は未だ求められない。

(高橋安人)

\section{9. 航空機及び航空発動機}

\section{$[80]$ 翼振れに及す翼巾の影響}

[Dipl.-Ing. Zbigniew Leliwa-Krzywoblocki, Aircraft Engg., 1941-3, Vol. XIII, No. 145, 頁 66〜67, 図 2, 裴 1] 本文は Dr. Roxbee Cox に依り提唱された方法を笑 用化したものである。先つ記号に就て还代る。

$V=$ 空气の速度 $V_{c}$ =翼振れに対する危險速陪 $s=$ 翼门 の $\frac{1}{2} c=$ 兾弦 (本均弦を使用するのが普通なり) $\quad c^{\prime}=$ 应 動する触の本均翼弦 (Küissner の式中にあるもの) $M=$

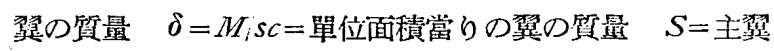
面積 $W_{w}=$ 主筫重量 $W=$ 機体重量 $k_{1}, k_{2}, k_{z}=$ 定数

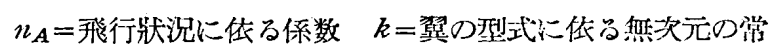

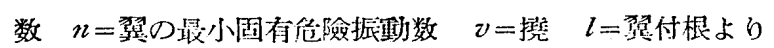

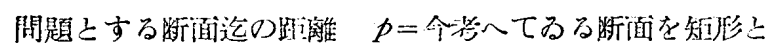

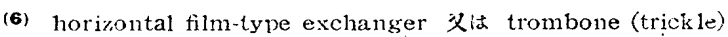
cooler. (7) batch heating 又位 cooling.

第 45 参第 304 号]

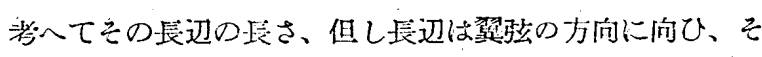
の長さは弦長に比例する $h=$ 同上短辺の長さとし、翼弦 に垂淔にして、断面の澡さ或は弦長に此例するものとす $F_{0}=$ 断面皘 $\sigma=$ 壁の原さ $G=$ 剪断剛性 $U=$ 考へてる

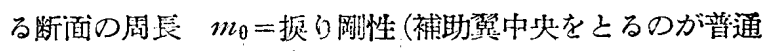
なり） $l_{\not}=$ 撓剛性

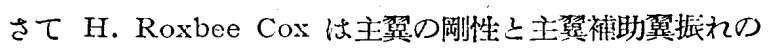
間の関係を統計的に研究し次の如き結論を得た。

若し据り薪 $Q$ が或断面を $\theta$ だけ回轉させた場合 Roxbee Cox はこの换り剛性は

$$
m_{\theta}=Q i \theta
$$

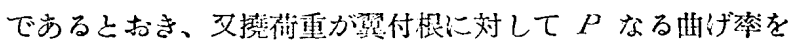

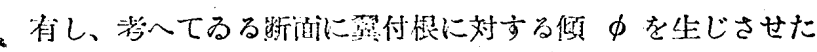

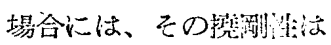

$$
l_{\phi}=P / \phi
$$

